Publisher homepage: www.universepg.com, ISSN: 2663-7529 (Online) \& 2663-7510 (Print) https://doi.org/10.34104/ejmhs.0190109

\title{
Effect of Antibiotic Susceptibility and Inhibitory Activity for the Control of Growth and Survival of Microorganisms of Extracts of Calendula officinalis
}

Md. Zulfiqer Shahen ${ }^{1}$, Shahriar Mahmud ${ }^{1 *}$, Shaharuq Nahid Sohana ${ }^{1}$, Mehadi Hasan Rony ${ }^{1}$, Md. Abu Sayeed Imran', Md. Abdullah Al Maruf ${ }^{2}$, Md. Afzal Ahmed Azim², Md Monirul Islam³, Md. Rokibul Islam $^{1}$, Md. Ekhlas Uddin ${ }^{1}$ and Mohammad Shah Alam ${ }^{4}$

${ }^{1}$ Dept. of Biotechnology and Genetic Engineering, Islamic University, Bangladesh; ${ }^{2}$ Dept. of Biochemistry and Molecular Biology, Jahangirnagar University, Bangladesh; ${ }^{3}$ Biolcon Group, Uttara, Dhaka, Bangladesh; ${ }^{4}$ Dept. of Microbiology, Gono Bishwabidyalay, Dhaka, Bangladesh.

*Correspondence: shahriar.btge@gmail.com

\section{ABSTRACT}

Extracts from various types of plants represent several evidences of beneficial health effects in the living system. Calendula officinalis is a most popular medicinal plant in our country. The purpose of the study was to determine the effectiveness of $C$. officinalis for the control of growth, and survival of microorganisms. Inhibition of growth was tested by the paper disc agar diffusion method. Minimum inhibitory concentration (MIC) was determined by the tube dilution method. C. officinalis leaf extract showed inhibition (MIC, inhibitory) to Escherichia coli, Klebsiella pneumoniae, and Bacillus subtilis and to the other bacteria tested. Antimicrobial effects of leaf extract of $C$. officinalis on some microorganisms including pathogens were analyzed. The extract of $C$. officinalis leaf which is prepared was tested on bacterial cultures such as B. subtilis, $S$. lutea, E. coli, K. pneumoniae, and also investigated that minimum inhibitory concentration (MIC) $4 \mu \mathrm{g} / \mathrm{ml}$ of leaf extract of $C$. officinalis in petroleum ether against $K$. pneumoniae and largest inhibitory zone are created by $512 \mathrm{mg} / \mathrm{ml}$ chloroform extract against $E$. coli leaf extract of $C$. officinalis in petroleum ether has showed better for antibacterial activity. The present study demonstrates that the potentiality of $C$. officinalis as a source of antimicrobials that could be harness for use in the health care delivery process.

Keywords: Calendula officinalis, Inhibitory agents, Leaf extract, and Disc agar diffusion method.

\section{INTRODUCTION:}

Nature is the potential source of medicinal agents and these agents have been used for thousands of years and numbers of modern drugs have been isolated from natural sources. Various medicinal plants have been used for years in daily life to treat various diseases all over the world. Approximately, amongst 1500 identified medicinal plants 500 are commonly in use (Chidambaram et al., 2014). Plants produce a diverse range of bioactive molecules (Uddin et al., 2017). Higher plants as a major source of medicinal compounds to play a 
dominant role in the maintenance of human health since ancient times (Farombi et al., 2003). The WHO estimates that $80 \%$ of the world population use herbal medicine for some aspects of primary health care purposes (Shinwari et al., 2009). There are 4,22,127 plant species growing on planet earth, about 35,000 to 70,000 plants species are used as medicinal plants (Hasan et al., 2007). The practice of traditional medicine is widespread in China, India, Japan, Pakistan, Sri Lanka and Thailand (Hasan et al., 2007). Calendula is used in ayurveda for the treatment of fever, diarrhea, and cancer (Krag et al., 2013).

Medicinal plants are one of the necessary and valuable resources in a wide range of natural resources that they can have an important role in health. C. officinalis is globally known for its medicinal importance containing various photochemical activities. Knowledge of the various biological activities and chemical constituents of medicinal plants are desirable not only for the discovery of new therapeutic agents but also for information in discovering new sources of other economic materials (Khaleqzzaman et al., 2002). Natural products have been a major source of the new drugs (Vuorelaa et al., 2004). The potential for developing antibacterial into medicine appears rewarding, from both the perspective of drug development and the perspective of phytomedicines (Rahaman et al., 2004). It possesses cytotoxic as well as abnormal cell growth reducing potential. Traditionally, C. officinalis was used as anti-inflammatory, diaphoretic, analgesic, anti-

\section{MATERIALS AND METHODS:}

Collection, Processing and Preservation of Calendula officinalis plant material - Healthy, disease free, mature C. officinalis plants was identified and selected for the collection of leaves from the garden of Kushtia $\left(23^{\circ} 54^{\prime} 37.1^{\prime \prime} \mathrm{N} 89^{\circ} 07^{\prime}\right.$ 20.9"E) and Jhenidah ( $\left.23^{\circ} 32^{\prime} 40.1^{\prime \prime} \mathrm{N} 89^{\circ} 10^{\prime} 27.8^{\prime \prime} \mathrm{E}\right)$ Pouroshova, Bangladesh. After cleaning the waste septic and in jaundice treatment (Chakraborthy et al., 2010). It is also used as a mouthwash after tooth extractions (Mukesh et al., 2011).

Phytopharmacological studies of different Calendula extracts have shown anti-viral activity, antiHIV properties of therapeutic interest, and antigenotoxic properties (Perez-Carreon et al., 2002). Calendula extract-containing creams and gels are commonly used to treat skin irritation, diabetes, inflammation, and burns, especially after radiotherapy, and to aid wound healing (Edwards et al., 2015). C. officinalis is widely cultivated as an herb and can be grown easily in sunny locations in most kinds of soils. C. officinalis are considered by many gardening experts as one of the most versatile flowers to grow in a garden, especially since they are easy to grow, and tolerate most soils. Pot marigolds typically bloom quickly from seed (in under two months) in bright yellows, golds, and oranges. Some scientists indicate the high antimicrobial activity of Calendula stems (Goyal et al., 2011). C. officinalis was very effective in inhibiting the growth of the zone of inhibition $E$. coli and B. subtilis of Petroleum ether and chloroform was found in $\mathrm{cm}$ respectively (Md et al., 2014). However, gm negative organisms are more sensitive to the extract of Calendula. It may be used as a constituent of a drug (Happy et al., 2018). The aim of the study was to identify bio-active chemical compounds from the flower of $C$. officinalis, their antimicrobial activity and setting up the standards specification.

materials of the leaf then plant material was air dried in room temperature. After 7 days the dried plant was grinded to form fine powder from the blender machine. This powder was used for the preparation of different solvents extracts by sequential extraction. The Good Agricultural and Field Collection Practices (GACP) of medicinal 
plants of World Health Organization (WHO) were followed strictly.

Solvents and Chemical used - In this experiment, only a few selected solvents are used such as petroleum ether and chloroform. Petroleum ether, chloroform, etc are used in this experiment.

Disk Preparation - The filter paper was punched with the punching machine and disc was made. The disc paper was taken into the test tubes \& sterilized in an autoclave for 15 minutes with 15 psi and $121^{\circ} \mathrm{C}$ temperatures.

Medium preparation - In this study, nutrient agar medium was used for antibacterial screening. For the test $2.8 \mathrm{gm}$ of the nutrient agar media was taken into $500 \mathrm{ml}$ autoclave conical flask. The media properly dissolved with the distilled water then sterilized in an autoclaved for 15 minutes with $121^{\circ} \mathrm{C}$. After autoclaving, the media was cooled for some time and poured into the autoclaved Petri dishes in the laminar airflow cabinet.

Inoculum preparation - $1 \mathrm{ml}$ of distilled water was taken into the screw-capped tube and the pure colony of freshly cultured bacteria was added into the tube and vortexes. The OD was measured with the colorimeter and microbial population was confirmed to be within tube. This suspension was used as inoculums.

Determination of minimum inhibitory concentration (MIC) of Calendula officinalis - MIC of the most active chloroform and petroleum ether extracts were determined using serial dilutions of $512 \mathrm{mg} / \mathrm{ml}, 512 \mu \mathrm{g} / \mathrm{ml}$ to $2 \mu \mathrm{g} / \mathrm{ml}$ in chloroform and petroleum ether solvent against both strains of $E$. coli in Agar well diffusion method as mentioned earlier. The lowest concentration of the extract required to inhibit the growth of the organism in vitro is MIC. In the present study, it was determined following the serial dilution technique.
Preparation of sample solution - Stock working solution of the plant extracts were prepared by dissolving $10 \mathrm{gm}$ of the dried extracts in $1 \mathrm{ml}$ each of petroleum ether and chloroform solvent into two separate flasks. From these solutions, $1 \mathrm{ml}$ solution was added to $9 \mathrm{ml}$ petroleum ether. Then from this $2^{\text {nd }}$ solution $8532 \mu 1$ was added to $1468 \mu 1$ chloroform. Therefore, the final concentration was reached to $512 \mu \mathrm{g} / \mathrm{ml}$. From these solutions, the 1 $\mathrm{ml}$ solution was added to $9 \mathrm{ml}$ petroleum ether. Then from this $2^{\text {nd }}$ solution $5688 \mu 1$ was added to $4312 \mu \mathrm{l}$ petroleum ether. Therefore, the final concentration was reached to $512 \mu \mathrm{g} / \mathrm{ml}$. 6hours extraction of 5.12grams seed powder was added to the $10 \mathrm{ml}$ chloroform and petroleum ether; therefore get mother solutions which were used without dilutions.

Serial dilution - For preparing $512 \mu \mathrm{g} / \mathrm{ml}$ to $2 \mu \mathrm{g} / \mathrm{ml}$, $1 \mathrm{ml}$ of solvent was added to each of nine screwcapped test tubes. $1 \mathrm{ml}$ of the sample having $512 \mu \mathrm{g} / \mathrm{ml}$ extracts was added to the first test tube containing $1 \mathrm{ml}$ of respective solvent and mixed well in the vortex and then $1 \mathrm{ml}$ of this solvent was transferred to the second test tube containing $1 \mathrm{ml}$ of the same solvent. After mixing well, $1 \mathrm{ml}$ of this mixture was transferred to the third test tube. This process of serial dilution was continued up to the last test tube. Finally, the concentration of the last test tube was $2 \mu \mathrm{g} / \mathrm{ml}$.

Preparation of disc - The disc paper was soaked with each concentration of extracts and placed at room temperature for air dry for 15 hours. Then dried disc paper was placed in the oven for 1 hour at $37^{\circ} \mathrm{C}$. After completion of oven dry, the disc paper was labeled according to different concentration and finally, the labeled disc paper was taken into the vial and it was ready for antibacterial activity.

Antimicrobial activity test - All strains used in the study were inoculated to nutrient agar and incubated at $35 \pm 0.1^{\circ} \mathrm{C}$ for $24 \mathrm{~h}$ and were allowed to 
grow until they reach $10^{8}-10^{9} \mathrm{cfu} / \mathrm{ml}$. Antibacterial activity studies were carried out for each test strains in duplicate and average measurement was calculated. Four organisms, (three gm-negative i.e. E. coli, Salmonella spp, Shigella spp, and Staphylococcus spp) were tested in this study to determine the antibacterial effect of crude extracts (Petroleum ether and Chloroform) C. officinalis.

Antibacterial activity of extracts and crude of $C$. officinalis was observed. Then in vitro antibacterial activities of the extracts were measured by employing standard agar disc diffusion method. Discs were impregnated with each treatment and control was assayed on duplicate agar medium

\section{RESULT AND DISCUSSION:}

\section{Petroleum ether extract of Calendula officinalis}

- Petroleum ether extract of $C$. officinalis exhibit antibacterial activity against $B$. subtilis, E. coil, $S$. lutea, K. pneumoniae. Different concentration of petroleum ether extract of Calendula $(512 \mathrm{mg} / \mathrm{ml})$ produced a zone of inhibition $1.7 \mathrm{~cm}$ against $B$. subtilis, $1.4 \mathrm{~cm}$ against $E$. coil, $1.6 \mathrm{~cm}$ against $S$. lutea, $1.5 \mathrm{~cm}$ against $K$. pneumoniae (Table 1).

Another concentration of petroleum ether extract of Calendula $(512 \mu \mathrm{g} / \mathrm{ml})$ produced a zone of inhibition $1.3 \mathrm{~cm}$ against $B$. subtilis, $1.1 \mathrm{~cm}$ against E. coil, $1.3 \mathrm{~cm}$ against $S$. lutea, $1.2 \mathrm{~cm}$ against $K$. pneumoniae (Table 1). And another concentration of petroleum ether extract of Calendula (256 $\mu \mathrm{g} / \mathrm{ml}$ ) produced a zone of inhibition $1.0 \mathrm{~cm}$ against $B$. subtilis, $1.0 \mathrm{~cm}$ against $E$. coil, $1.2 \mathrm{~cm}$ against $S$. lutea, $1.0 \mathrm{~cm}$ against $K$. pneumoniae (Table 1).

Similarly, concentration of petroleum ether extract of Calendula $(128 \mu \mathrm{g} / \mathrm{ml})$ produced a zone of inhibition $0.9 \mathrm{~cm}$ against $B$. subtilis, $1.0 \mathrm{~cm}$ against $E$. coil, $1.0 \mathrm{~cm}$ against $S$. lutea, $1.0 \mathrm{~cm}$ against $K$. pneumoniae (Table 1). plate for E. coli, Shigella spp, Staphylococcus spp, and Salmonella spp. The experiment was replicated two times to confirm the reproducible results. Sterile, blank paper discs were impregnated with only sterile solvent (Petroleum ether and Chloroform) and used as negative control each time. Standard Kanamycin $(30 \mu \mathrm{g})$ and Strepto-mycin $(5 \mu \mathrm{g})$ were used as a positive control for comparison of the antibacterial activity.

Statistical analysis - The Statistical analysis was performed by using SPSS software (release 10.0) to find out significant differences in the antibacterial effects.

The concentration of petroleum ether extract of $C$. officinalis $(64 \mu \mathrm{g} / \mathrm{ml})$ produced a zone of inhibition $0.8 \mathrm{~cm}$ against $B$. subtilis, $0.9 \mathrm{~cm}$ against $E$. coil, $0.8 \mathrm{~cm}$ against $S$. lutea, $0.9 \mathrm{~cm}$ against $K$. pneumoniae (Table 1). The concentration of petroleum ether extract of Calendula $(32 \mu \mathrm{g} / \mathrm{ml})$ produced zone of inhibition $0.6 \mathrm{~cm}$ against $B$. subtilis, $0.9 \mathrm{~cm}$ against $E$. coil, $0.6 \mathrm{~cm}$ against $S$. lutea, $0.8 \mathrm{~cm}$ against $K$. pneumoniae (Table 1).

The concentration of petroleum ether extract of Calendula $(16 \mu \mathrm{g} / \mathrm{ml})$ produced zone of inhibition $0.6 \mathrm{~cm}$ against $B$. subtilis, $0.8 \mathrm{~cm}$ against $E$. coil, $0.5 \mathrm{~cm}$ against $S$. lutea, $0.7 \mathrm{~cm}$ against $K$. pneumoniae (Table 1).

The concentration of petroleum ether extract of Calendula $(8 \mu \mathrm{g} / \mathrm{ml})$ produced zone of inhibition $0.4 \mathrm{~cm}$ against $B$. subtilis, $0.4 \mathrm{~cm}$ against $E$. coil, no zone against $S$. lutea and $0.7 \mathrm{~cm}$ against $K$. pneumoniae (Table 1). 
Table 1: Comparison of antibacterial activity and MIC values of leaf extract of $C$. officinalis in petroleum ether by inhibition zone.

\begin{tabular}{|c|c|c|c|c|c|c|c|c|c|c|c|c|}
\hline \multirow[t]{2}{*}{ Test strains } & \multicolumn{12}{|c|}{ Petroleum ether extract of Calendula officinalis leaf (Dose $\mu \mathrm{g} / \mathrm{ml}$ ) } \\
\hline & $\begin{array}{l}512 \\
\mathrm{mg} / \\
\mathrm{ml}\end{array}$ & $\begin{array}{l}512 \\
\mu \mathrm{g} / \\
\mathrm{ml}\end{array}$ & $\begin{array}{l}256 \\
\mu \mathrm{g} / \\
\mathrm{ml}\end{array}$ & $\begin{array}{c}128 \\
\mu \mathrm{g} / \\
\mathrm{ml}\end{array}$ & $\begin{array}{l}64 \\
\mu \mathrm{g} / \\
\mathrm{ml}\end{array}$ & $\begin{array}{l}32 \\
\mu \mathrm{g} / \\
\mathrm{ml}\end{array}$ & $\begin{array}{l}16 \\
\mu \mathrm{g} / \\
\mathrm{ml}\end{array}$ & $\begin{array}{l}8 \\
\mu \mathrm{g} / \\
\mathrm{ml}\end{array}$ & $\begin{array}{l}4 \\
\mu \mathrm{g} / \\
\mathrm{ml}\end{array}$ & $\begin{array}{l}2 \\
\mu \mathrm{g} / \\
\mathrm{ml}\end{array}$ & Positive & Negative \\
\hline B. subtilis & $\begin{array}{l}1.7 \\
\mathrm{~cm}\end{array}$ & $\begin{array}{l}1.3 \\
\mathrm{~cm}\end{array}$ & $\begin{array}{l}1.0 \\
\mathrm{~cm}\end{array}$ & $\begin{array}{l}0.9 \\
\mathrm{~cm}\end{array}$ & $\begin{array}{l}0.8 \\
\mathrm{~cm}\end{array}$ & $\begin{array}{l}0.6 \\
\mathrm{~cm}\end{array}$ & $\begin{array}{l}0.6 \\
\mathrm{~cm}\end{array}$ & $\begin{array}{l}0.4 \\
\mathrm{~cm}\end{array}$ & - & - & $2.3 \mathrm{~cm}$ & - \\
\hline E. coli & $\begin{array}{l}1.4 \\
\mathrm{~cm}\end{array}$ & $\begin{array}{l}1.1 \\
\mathrm{~cm}\end{array}$ & $\begin{array}{l}1.0 \\
\mathrm{~cm}\end{array}$ & $\begin{array}{l}1.0 \\
\mathrm{~cm}\end{array}$ & $\begin{array}{l}0.9 \\
\mathrm{~cm}\end{array}$ & $\begin{array}{l}0.9 \\
\mathrm{~cm}\end{array}$ & $\begin{array}{l}0.8 \\
\mathrm{~cm}\end{array}$ & - & - & - & $2.5 \mathrm{~cm}$ & - \\
\hline S. lutea & $\begin{array}{l}1.6 \\
\mathrm{~cm}\end{array}$ & $\begin{array}{l}1.3 \\
\mathrm{~cm}\end{array}$ & $\begin{array}{l}1.2 \\
\mathrm{~cm}\end{array}$ & $\begin{array}{l}1.0 \\
\mathrm{~cm}\end{array}$ & $\begin{array}{l}0.8 \\
\mathrm{~cm}\end{array}$ & $\begin{array}{l}0.6 \\
\mathrm{~cm}\end{array}$ & $\begin{array}{l}0.5 \\
\mathrm{~cm}\end{array}$ & $\begin{array}{l}0.4 \\
\mathrm{~cm}\end{array}$ & - & - & $\begin{array}{l}2.5 \\
\mathrm{~cm}\end{array}$ & - \\
\hline K. pneumoniae & $\begin{array}{l}1.5 \\
\mathrm{~cm}\end{array}$ & $\begin{array}{l}1.2 \\
\mathrm{~cm}\end{array}$ & $\begin{array}{l}1.0 \\
\mathrm{~cm}\end{array}$ & $\begin{array}{l}1.0 \\
\mathrm{~cm}\end{array}$ & $\begin{array}{l}0.9 \\
\mathrm{~cm}\end{array}$ & $\begin{array}{l}0.8 \\
\mathrm{~cm}\end{array}$ & $\begin{array}{l}0.7 \\
\mathrm{~cm}\end{array}$ & $\begin{array}{l}0.7 \\
\mathrm{~cm}\end{array}$ & $\begin{array}{l}0.7 \\
\mathrm{~cm}\end{array}$ & - & $2.5 \mathrm{~cm}$ & - \\
\hline
\end{tabular}

The concentration of petroleum ether extract of Calendula $(4 \mu \mathrm{g} / \mathrm{ml})$ produced a zone of inhibition only $0.7 \mathrm{~cm}$ against $K$. pneumoniae (Table $\mathbf{1}$ ). In
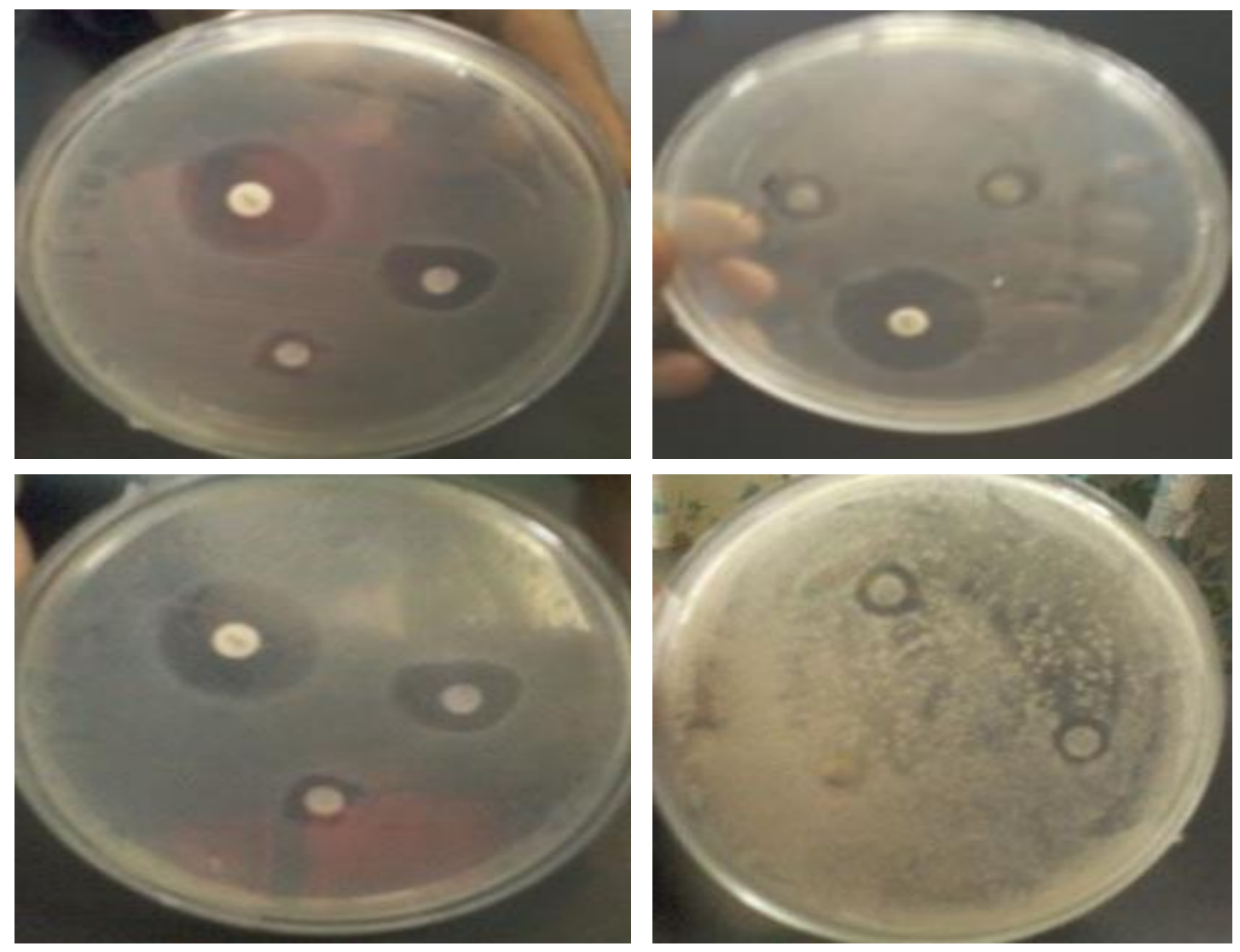

Fig 1: Comparison of Antibacterial activity and MIC values of leaf extract of $C$. officinalis in petroleum ether by inhibition zone. 
Photochemical analysis of Solvents and Chemical - Photochemical analysis showed that almost all the solvents are responsible for extracting different components from the plants. Plant pharmacological studies have suggested that Calendula extracts have anti-viral, anti-genotoxic and anti-inflammatory properties (Eva Jimenez-Medina et al., 2006).
The Chloroform extract of Calendula officinalis - Chloroform extract of C. officinalis exhibit antibacterial activity against $B$. subtilis, $E$. coil, S. lutea, K. pneumoniae. Different concentration of chloroform extract of Calendula (512 $\mathrm{mg} / \mathrm{ml}$ ) produced a zone of inhibition $1.7 \mathrm{~cm}$ against $B$. subtilis, $1.8 \mathrm{~cm}$ against $E$. coil, $1.6 \mathrm{~cm}$ against $S$. lutea, $1.7 \mathrm{~cm}$ against $K$. pneumoniae (Table 2).

Table 2: Comparison of antibacterial activity and MIC values of leaf extract of $C$. officinalis in chloroform by inhibition zone.

\begin{tabular}{|l|l|l|l|l|l|l|l|l|l|l|l|l|}
\hline Test strains & \multicolumn{10}{l|}{ Chloroform extract of Calendula officinalis leaf (Dose $\mu \mathrm{g} / \mathrm{ml})$} \\
& 512 & 512 & 256 & 128 & 64 & 32 & 16 & 8 & 4 & 2 & Positive & Negative \\
& $\mathrm{mg} /$ & $\mu \mathrm{g} /$ & $\mu \mathrm{g} /$ & $\mu \mathrm{g} /$ & $\mu \mathrm{g} /$ & $\mu \mathrm{g} /$ & $\mu \mathrm{g} /$ & $\mu \mathrm{g} /$ & $\mu \mathrm{g} /$ & $\mu \mathrm{g} /$ & control \\
& $\mathrm{ml}$ & $\mathrm{ml}$ & $\mathrm{ml}$ & $\mathrm{ml}$ & $\mathrm{ml}$ & $\mathrm{ml}$ & $\mathrm{ml}$ & $\mathrm{ml}$ & $\mathrm{ml}$ & $\mathrm{ml}$ & \\
\hline B. subtilis & 1.7 & 1.5 & 1.2 & 0.8 & 0.7 & - & - & - & - & - & 2.3 & - \\
& $\mathrm{cm}$ & $\mathrm{cm}$ & $\mathrm{cm}$ & $\mathrm{cm}$ & $\mathrm{cm}$ & & & & & & $\mathrm{cm}$ & \\
\hline E. coli & 1.8 & 1.6 & 1.2 & 0.9 & 0.7 & - & - & - & - & - & 2.5 & - \\
& $\mathrm{cm}$ & $\mathrm{cm}$ & $\mathrm{cm}$ & $\mathrm{cm}$ & $\mathrm{cm}$ & & & & & & $\mathrm{cm}$ & \\
\hline S. lutea & 1.6 & 1.4 & 1.2 & 1.0 & 0.8 & 0.6 & 0.6 & 0.5 & 0.5 & - & 2.5 & - \\
& $\mathrm{cm}$ & $\mathrm{cm}$ & $\mathrm{cm}$ & $\mathrm{cm}$ & $\mathrm{cm}$ & $\mathrm{cm}$ & $\mathrm{cm}$ & $\mathrm{cm}$ & $\mathrm{cm}$ & & $\mathrm{cm}$ & \\
\hline K. & 1.7 & 1.5 & 1.3 & 1.1 & 0.8 & 0.7 & 0.5 & - & - & - & 2.5 & - \\
pneumoniae & $\mathrm{cm}$ & $\mathrm{cm}$ & $\mathrm{cm}$ & $\mathrm{cm}$ & $\mathrm{cm}$ & $\mathrm{cm}$ & $\mathrm{cm}$ & & & & $\mathrm{cm}$ & \\
\hline
\end{tabular}

Another concentration of chloroform extract of Calendula $(512 \mu \mathrm{g} / \mathrm{ml})$ produced zone of inhibition $1.5 \mathrm{~cm}$ against $B$. subtilis, $1.6 \mathrm{~cm}$ against $E$. coil, $1.4 \mathrm{~cm}$ against $S$. lutea, $1.5 \mathrm{~cm}$ against $K$. pneumoniae (Table 2). And another concentration of chloroform extract of Calendula $(256 \mu \mathrm{g} / \mathrm{ml})$ produced a zone of inhibition $1.2 \mathrm{~cm}$ against $B$. subtilis, $1.2 \mathrm{~cm}$ against $E$. coil, $1.2 \mathrm{~cm}$ against $S$. lutea, $1.3 \mathrm{~cm}$ against $K$. pneumoniae (Table 2). The concentration of chloroform extract of Calendula $(128 \mu \mathrm{g} / \mathrm{ml})$ Produced zone of inhibition $0.8 \mathrm{~cm}$ against $B$. subtilis, $0.9 \mathrm{~cm}$ against $E$. coil, $1.0 \mathrm{~cm}$ against $S$. lutea, $1.1 \mathrm{~cm}$ against $K$. pneumoniae (Table 2).

The concentration of chloroform extract of Calendula $(64 \mu \mathrm{g} / \mathrm{ml})$ produced zone of inhibition $0.7 \mathrm{~cm}$ against $B$. subtilis, $0.7 \mathrm{~cm}$ against $E$. coil,
$0.8 \mathrm{~cm}$ against $S$. lutea, $0.8 \mathrm{~cm}$ against $K$. pneumoniae (Table 2). The concentration of chloroform extract of Calendula $(16 \mu \mathrm{g} / \mathrm{ml})$ produced zone of inhibition $0.0 \mathrm{~cm}$ against $B$. subtilis, $0.0 \mathrm{~cm}$ against $E$. coil, $0.6 \mathrm{~cm}$ against $S$. lutea, $0.5 \mathrm{~cm}$ against $K$. pneumoniae (Table 2).

The concentration of chloroform extract of Calendula $(8 \mu \mathrm{g} / \mathrm{ml})$ produced zone of inhibition $0.5 \mathrm{~cm}$ against $S$. lutea (Table 2). The concentration of chloroform extract of Calendula $(32 \mu \mathrm{g} / \mathrm{ml})$ produced zone of inhibition $0.0 \mathrm{~cm}$ against $B$. subtilis, $0.0 \mathrm{~cm}$ against $E$. coil, $0.6 \mathrm{~cm}$ against $S$. lutea, $0.7 \mathrm{~cm}$ against $K$. pneumoniae (Table 2). The concentration of chloroform extract of Calendula $(4 \mu \mathrm{g} / \mathrm{ml})$ produced zone of inhibition $0.5 \mathrm{~cm}$ only against $S$. lutea (Table 2 ). 

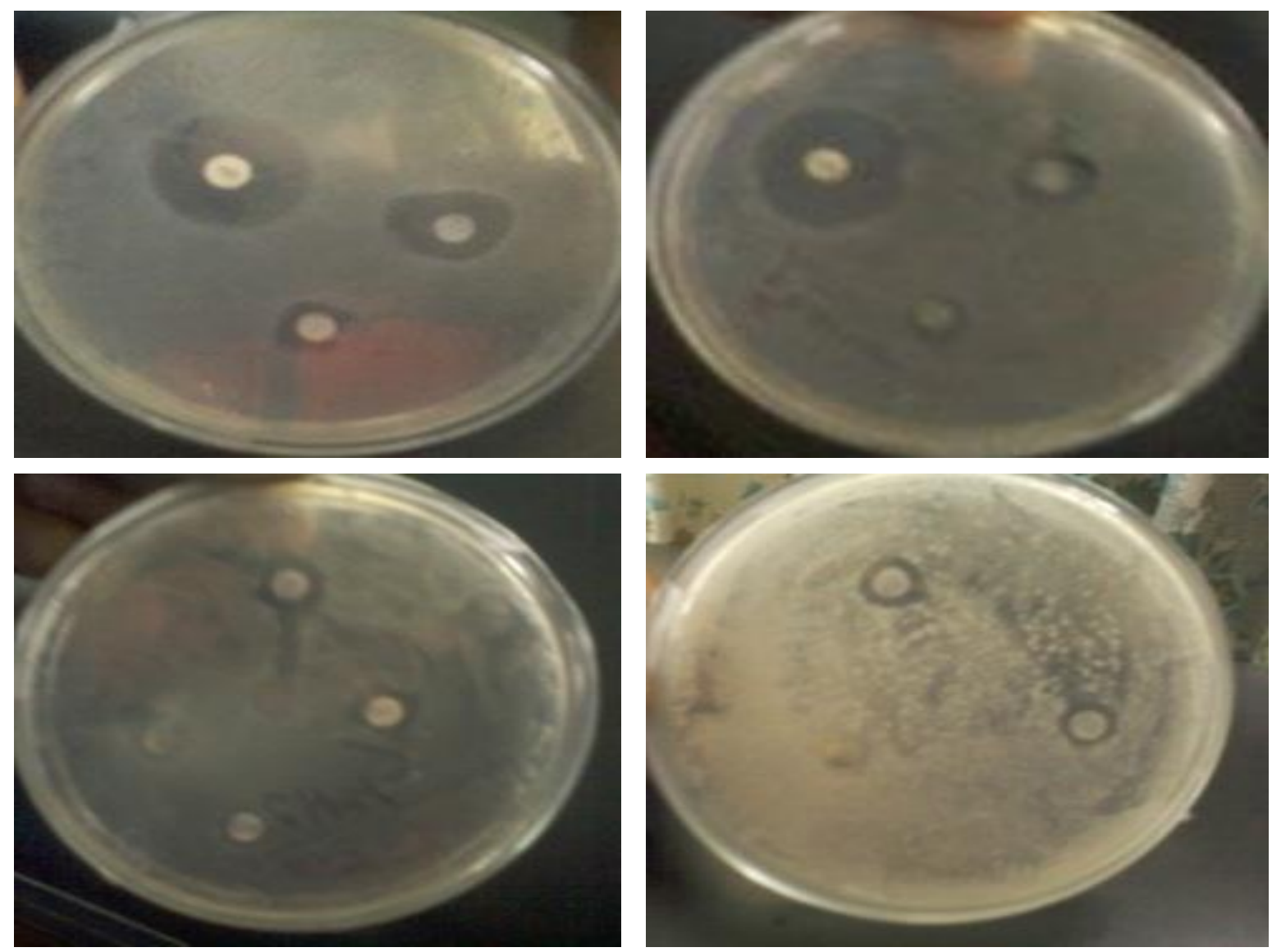

Fig 2: Comparison of Antibacterial activity and MIC values of leaf extract of C. officinalis in chloroform by inhibition zone.

In addition, the MIC value was also $(0.5 \mathrm{~cm})$ determined. The MIC values against $S$. lutea were 4 ugml-1. For the comparison of the plant extracts activity positive control (different type of antibiotic disc) and negative control (only solvent absorbing disc) was used. The negative control showed no activity against all tested bacteria. The positive control showed significant antibacterial activity against all bacteria.

The petroleum ether and chloroform extracts of C. officinalis showed the highest antibacterial activity against $E$. coli and $K$. pneumonia. In the present study, $C$. officinalis was very effective in inhibiting the growth of $E$. coil the zone of inhibition of petroleum ether and chloroform was found. The inhibition of the effect of $C$. officinalis on E. coli was less than that of to Neomycin (30ug) and also investigated that minimum inhibitory concentration $2 \mu \mathrm{g} / \mathrm{ml}$ of leaf extract of $C$. officinalis in chloroform against $K$. pneumoniae and $E$. coli and in petroleum ether against $E$. coli.

The largest inhibitory zone is created by 512 $\mathrm{mg} / \mathrm{ml}$ chloroform extract against $E$. coli. The extract of $C$. officinalis has been reported to possess antibacterial activity; however, gramnegative bacteria are more susceptible to the action of the oil, whereas gram-negative organisms are more sensitive of the leaves extract (Ali and Blunden et al., 2003). 


\section{CONCLUSION:}

The beneficial health effects of extracts from many types of plants that have been used for years in daily life to treat diseases all over the world. In the present study, the extract of leaves displayed a variable degree of anti-microbial activity on different microorganisms. $E$. coli and $K$. pneumoniae were found to be more sensitive strain than the others. On the other hand, B. subtilis and S. lutea were found to be more resistant bacteria against the $C$. officinallis leaves examining findings, the widest inhibition zone was formed $E$. coli and $K$. pneumonia around. The least inhibitory effects were observed for $E$. coli. The petroleum ether and

\section{ACKNOWLEDGEMENT:}

The research project was financially supported with proper guidance and help for data analysis in the Dept. of Biotechnology and Genetic Engineering, Islamic University, Bangladesh. Many thanks, to the co-workers supporting for successful completion of the research work.

\section{REFERENCES:}

1. Ali BH., and Blunden G. (2003). Pharmacological and Toxicological Properties of Nigella sativa. Phytotherapy Research. 17, 299-305.

https://pubmed.ncbi.nlm.nih.gov/12722128/

2. Chakraborthy GS. (2010). Phytochemical screening of Calendula officinalis Linn leaf extract by TLC. Int J. Res Ayurveda Pharm. 1(1):131-134.

3. Chidambaram J, Saritha K, Maheswari R and Muzammil MS. (2014). Efficacy of green synthesis of silver nanoparticles using flowers of Calendula officinalis. Chem Sci Trans. 3, 773-777.

4. Edwards, S.E., Costa Rocha, I., Williamson, E.M., Heinrich, M. (2015). Phytopharmacy: chloroform extracts of Calendula showed antibacterial activity against E. coli and B. subtilis. In conclusion, this result indicated that extracts of the $C$. officinalis leaves which were prepared using petroleum ether and chloroform have a strong inhibitory activity on some pathogens. The purpose was to examine the inhibitory effects of $C$. officinalis leaves extract, some bacteria causing poisoning and harmful for humans. So, the further microbiological investigation was confined only on petroleum ether and chloroform fraction and also investigation is necessary to confirm the bioactive principles of the $C$. officinalis in Bangladesh.

\section{CONFLICTS OF INTEREST:}

The authors declared no potential conflicts of the interest with respect to the research, authorship and/or publication of this article.

An Evidence-Based Guide to Herbal Medicinal Products. ISBN: 978-1-11854356-6, 414 pages, Wiley-Blackwell.

5. Eva Jiménez-Medina, Angel Garcia-Lora, Laura Paco, Ignacio Algarra, Antonia Collado and Federico Garrido. (2006). A new extract of the plant Calendula officinalis produces a dual in vitro effect: cytotoxic antitumor activity and lymphocyte activation, BMC Cancer. 6(1): 1-14.

6. Farombi Eo. (2003). African indigenous plants with chemotherapeutic potentials and biotechnological approach to the production of bioactive prophylactic agents. African J. Biotech. 2, 662-671. https://doi.org/10.5897/AJB2003.000-1122 
7. Goyal M., Goyal R., Goyal M. (2011). Antimicrobial and phytochemical estimation of Calendula officinalis against human pathogenic microorganisms. International $J$. of Innovations in Bio-Sciences, 1, 1-10.

8. Happy A. H., Alam M. G., Mahmud S., Uddin M. E. (2018). Isolation, identification $\&$ characterization of gram-negative bacteria from popular street food (Chotpoti) at Savar area, Dhaka, Bangladesh, Open Access Library J. 5, e4986. https://doi.org/10.4236/oalib.1104986

9. Hasan A, Khan Ma, Ahmad M. (2007). The Authenticity of folk medicinal plants of Pakistan. Taxonomic Chemical methods. 1, 1-5.

10. Khalequzzaman M, Gazi MMR, and Das BC. (2002). Antimicrobial activities of the Rhizome and Leaf Extracts of Zingiber cassumunar Roxb. Bangladesh J. Genet. Biotechnol. 3, 35-40.

11. Krag K. et al. (2013). Genetic parameters for milk fatty acids in Danish Holstein cattle based on SNP markers using a Bayesian approach. BMC Genetics. 14: 1-10.

12. Md. Ekhlas Uddin, Pulak Maitra, Hossain Md. Faruquee, Md. Firoz Alam, (2014). Isolation and characterization of proteases enzyme from locally isolated Bacillus sp., American Journal of Life Sciences. 2(6), 338-344. https://doi.org/10.11648/j.ajls.20140206.12

13. Mukesh S, Pankaj S, Nagori K, et al. (2011). Organoleptic properties in-vitro and in-vivo pharmacological activities of Calendula offi- cinalis Linn. J. Chem Pharm Res. 3(4): 655663.

14. Perez-Carreon JI, Cruz-Jimenez G, LiceaVega JA, Arce-Popoca E, Fattel-Fazenda S, Villa-Trevino $S$ (2002). Genotoxic and antigenotoxic properties of Calendula officinalis extract in rat liver cell cultures treated with diethylnitrosamine. Toxicol in Vitro. 16: 253-258.

https://pubmed.ncbi.nlm.nih.gov/12020598/

15. Rahman A, Parvez MAK, Parvin T, Paul DK, and Sattar MA. (2004). Antimicrobial activity of three bioactive compounds from the stream bark of Piper chaba Hunter. Bioscien. Res. 1(1), 16-20.

16. Shinwari Zk, Watanabe T, Rehman M, Yoshikawa TA. (2009). Assessment of antibacterial activity of three plants used in Pakistan to cure respiratory diseases. African Journal of Biotechnology. 8(24), 7082-7086.

17. Uddin M. E., Ahmad T., Ray S. K., and Ahammed T. (2017). Thermotolerant extracellular proteases produced by Bacillus subtilis isolated from local soil that repressenting industrial application. J. of Pure and Applied Microbiol. 11(2), 733-741.

https://doi.org/10.22207/JPAM.11.2.12

18. Vuorela P, Leinonenb M, Saikkuc P, Tammella P, Rauhsd J P, Wennberge T, and Vuorela H. (2004). Natural products in the process of finding new drug candidates. Curr. Med. Chem. 11(11), 1375-1389.

Citation: Shahen MZ, Mahmud S, Rony MH, Sohana SN, Imran MAS, Al Maruf MA, Azim MAA, Islam MM, Islam MR, Uddin ME, and Alam MS. (2019). Effect of antibiotic susceptibility and inhibitory activity for the control of growth and survival of microorganisms of extracts of Calendula officinalis. Eur. J. Med. Health Sci., 1(3), 1-9. https://doi.org/10.34104/ejmhs.0190109 @ @ 